\title{
Effect of rainfall regimes on seed production and quality of Avena barbata
}

\author{
Alfredo Olivares, Myrna Johnston, and Carolina Calderón \\ Facultad de Ciencias Agronómicas, Universidad de Chile \\ Santa Rosa 11315, La Pintana, Santiago, Chile.
}

\begin{abstract}
A. Olivares, M. Johnston, and C. Calderón. 2009. Effect of rainfall regimes on seed production and quality of Avena barbata. Cien. Inv. Agr. 36(1): 69-76. The effects of rainfall amount and distribution on seed yield and quality in Avena barbata were evaluated in a greenhouse under controlled conditions with simulated rainfall regimes. A randomized complete-block design was used with five replications of one pot each. Seven treatments were established according to rainfall regimes for a real year in the semiarid zone in the Metropolitan Region, Chile: normal rainfall (1982), late rainfall (1987), normal-early rainfall (1962), normallate rainfall (1989), dry-early rainfall (1981) and dry-late rainfall (1990). One treatment without water stress was left for comparison. One-year-old seeds were planted in pots with disinfected soil. The five most uniform plants in terms of size and health were chosen for the experiments. The simulated rainfalls were applied according to calendar dates of each selected year. The roots' and shoots' mass production was evaluated. The number of floral shoots, fruits and seeds; their total weights and separating annexes; as well as the number of filled seeds, seed viability and germination were also determined. Based on the results obtained, a rainy year with late rainfall distribution highly favored mass production; in addition, the seeds' quality was better in years with late rainfall distribution, normal or rainy. The proportion of filled seeds was greater in the rainy-normal rainfall year, and the seed annexes were better in the late rainy year. The results indicate that the production, quality of grains and phenology of $A$. barbata were modified with the rainfall distribution.
\end{abstract}

Key words: Avena, development, growth, seeds, water stress.

\section{Introduction}

The development of an annual prairie in a Mediterranean climate is characterized by a strong seasonality that is essentially the consequence of rainfalls, temperatures and photoperiods (Olivares et al., 1998; Castellaro and Squella,

Received 24 April 2008. Accepted 30 September 2008. Corresponding author: agolivare@gmail.com
2006). The species composing this prairie have a sequence in their phenophases, related to the constancy of minimum climatic requirements to reach each phenological state. Thus, there are precocious species (e.g., Erodium botrys and Vulpia bromoides) and late species (e.g., Avena barbata and Bromus berteroanus) (Castellaro et al., 1994).

Seedling emergence is determined by several factors, with water availability being the most important factor (Herrera et al., 2008). Water availability also affects the proportion of seeds 
with tegumentary dormancy and the proportion of nonviable seeds (Johnston et al., 1998a).

A prairie's composition will be the consequence of the success of its species in their seedlings' emergence and establishment. This has a direct relation with the beginning of autumn rains and the occurrence of dry periods after germination, which allow the expression of differential capacities of the species to germinate according to the temperature and their resistance to early droughts ("false break"). Species of the genus Erodium have shown a high resistance to "false break", but $A$. barbata has been shown to be more sensitive to reductions in soil humidity than "false break" (Olivares et al., 1997; Olivares and Ormazábal, 2006). The most critical stages for survival of the different therophytes are germination, emergence and establishment; where germination is a risky point between the more tolerant to drought and to extreme temperatures stage of the resting seed and the weakest and most vulnerable stage that corresponds to plantlet emergence, which, according to Marques and Olivera (2008), is correlated with mean temperature, precipitation and photoperiod.

The rainfall regimen of the semiarid dryland is characterized by great variability, and the natural and/or naturalized therophytes adapt to it, causing the emergence to establishment period and the growth rate to vary (Olivares et al., 1998). In addition, when facing water stress, plants manifest changes in the number and size of their reproductive structures, which allows them to survive in difficult conditions (Aronson et al, 1993). There is a positive correlation between the cross-pollination rate and the annual average precipitation and a negative correlation between the crossed pollination rate and the average monthly temperature during Hordeum vulgare and $H$. spontaneum flowering (Ghani et al., 2002).

It has also been proved that plants under conditions of water stress modify the length and biomass of their roots, increasing the development of radical hairs, which allows a larger contact surface with the soil and, therefore, better use of water (Huang and Gao, 2000). Other works have indicated that plants respond by increasing the proportion of assimilates toward the roots, which increases their growth (Huang and Fry, 1998).

With these factors in mind, the evaluation of the effects of some extreme dryland rainfall regimens of the Metropolitan Region, Chile, on $A$. barbata growth and development was proposed as a goal. Specifically, it was decided to investigate how variations in the amount and distribution of precipitation determine seed quality and yield.

\section{Materials and methods}

\section{Vegetal material}

Plants of $A$. barbata were cultivated in $50-\mathrm{cm}-$ deep black polyethylene pots $13 \mathrm{~cm}$ in diameter, with soil from the Piedmont Cuesta Barriga series, Typic Haploxerolls, previously treated with $98 \%$ methyl bromide ( $48 \mathrm{~h}$, ventilated for 7 days) to inactivate the remaining seeds. The soil was sieved at $5 \mathrm{~mm}$ and mixed with $10 \%$ of expanded polystyrene spheres of equal diameter. Ten seeds were sowed per pot, choosing seeds with larger size and grain filling. After emergence, the five strongest and most uniform plants were left in each pot.

\section{Rainfall regimens}

Six rainfall regimens were studied in the pots, which were kept in a cold greenhouse at mean temperatures of 15 to $26^{\circ} \mathrm{C}$ and mean relative humidity between 64 and $73 \%$. These rainfall regimes were chosen according to the results obtained previously with Bromus berteroanus (Johnston et al., 2005). The volume of water applied and timing were decided according to the rainfall regimes for each of the selected years. In addition, a treatment with no water restriction, kept at $66.7 \%$ field capacity of the soil, was added for comparison. The rainfall regime corresponding to each type of year was applied with a serum dispenser, simulating drip irrigation and allowing the total water equivalent of each rain to be incorporated in $24 \mathrm{~h}$. 
In the rainfall regimens applied, amount and distribution of rains were combined (Figure 1). Rainy (R), normal (N) and dry (D) indicate the total amount of rain, and normal (n), late (la) and early (ea) indicate their distribution (Olivares et al., 2006). Therefore, the rainfall regimens simulated were: 1 . Rainy with normal rain distribution $(\mathrm{Rn})$, year $1982(628 \mathrm{~mm})$. 2. Rainy with late rain distribution (Rla), year 1987 (671 mm). 3. Normal with early rain distribution (Nea), year $1962(228 \mathrm{~mm}), 4$. Normal with late rain distribution (Nla), year 1989 (281 mm). 5. Dry with early rain distribution (Dea), year 1981 (225 $\mathrm{mm}$ ). 6. Dry late rain distribution (Dla), year $1990(157 \mathrm{~mm})$, and 7. Without water restriction, equivalent to a $66.7 \%$ soil field capacity, adding water in amounts determined by the weighted difference of the flower pots with respect to initial contents equivalent to $50 \mathrm{~mm}$ of rain.

\section{Evaluation}

Reproductive growth was evaluated in each treatment by the total number of stems and seeds produced; total weight and seed quality were evaluated by recording the proportion of

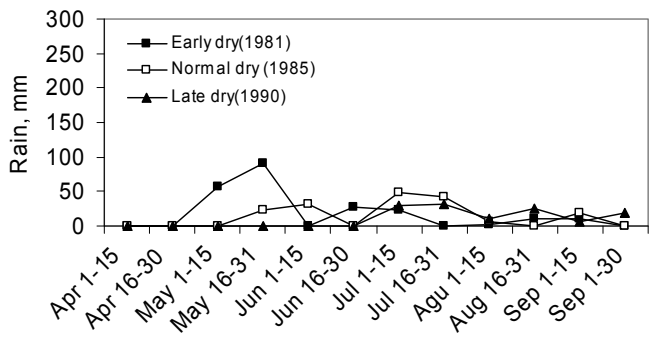

palea, lemma and awn (annexes) of seeds per plant and seed filling, separating vain seeds from those with abundant reserves, the weight of 100 seeds, feasibility and germination. The germination tests were conducted on filter paper moistened with water at $20^{\circ} \mathrm{C}$. Seed viability was determined with $1 \%$ of $2,3,5$ triphenyl-tetrazolium chloride for $24 \mathrm{~h}$ at $25^{\circ} \mathrm{C}$ following the protocol of ISTA (2008) for A. sativa.

The vegetative growth was evaluated in the 25 plants per treatment by determining shoot and root mass, expressed as dry matter at the end of plant cycle. In order to obtain roots, the soil from each pot was introduced into a mesh immersed in water for $24 \mathrm{~h}$; then, the roots were separated over a fine grid with the help of a soft water splash. The collected material was dried in a forced air stove at $70^{\circ} \mathrm{C}$ for $48 \mathrm{~h}$. The root/ shoot ratio was determined from the dry average weights obtained in each treatment. In addition, the reproductive index $(\mathrm{RI}=$ total number of seeds per plant/ total dry weight per plant) and reproductive efficiency index (REI $=$ the relation between full fruit weight and the vegetative aerial and roots dry matter) were estimated (Aronson et al., 1993). The phenological stages of plant development were also determined by

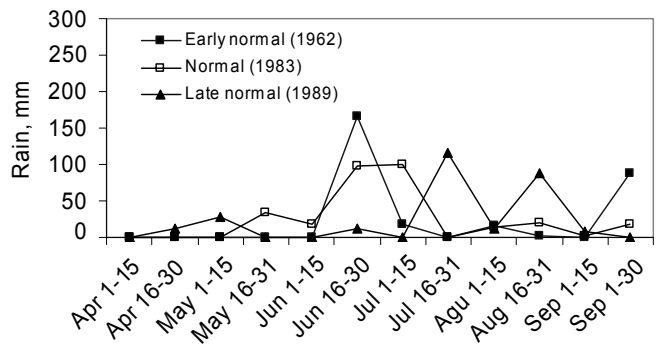

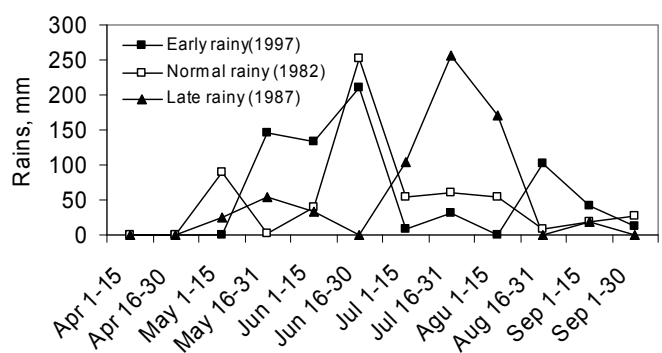

Figure 1. Rainfall distribution for different rainfall regimes selected in this study. 
recording the beginning and end of the emergence, cluster, stem elongation, flowering, seed formation, seed maturation and leaf senescence. Each phenophase was determined to be present when it was observed in half of the plants per treatment.

\section{Design and statistical analysis}

Treatments were distributed according to a randomized complete block design with five repetitions. The experimental unit was a single pot each with five plants. For germination and viability tests, eight repetitions were used with 25 seeds each. The results were studied for variance, and means were separated according to Student-Neuman-Keuls $(\mathrm{SNK})(\mathrm{p} \leq 0.05)$. In the case of discrete variables, the values were previously transformed in Bliss degrees.

\section{Results and discussion}

The statistical analysis performed for each variable showed, in most cases, significant differences between the reference treatment without water restriction and the different rainfall regimens simulated in this work, which included water deficits of different magnitudes. As these differences were also very large numerically, the reference treatment was excluded in a second analysis to compare only the plants' responses to the diverse rainfall regimens simulated in this investigation.

While distribution of aerial dry matter production tended to be superior with the highest total precipitation, rain distribution corresponding to the late-rainy year determined the largest differences among treatments (Figure 2). In this way, it was possible to prove that it is possible to obtain equal production of dry matter with different total amounts of precipitation under normal and late rain distributions, in rainy and normal years, respectively. The effect of the precipitation distribution was so evident that, in spite of the higher rainfall of the normal rainy year ( 628 $\mathrm{mm}$ ), the dry matter production was equal to the production obtained under a normal-late rainy year with only $281 \mathrm{~mm}$ of rain. It is noteworthy that the production obtained in the reference treatment, with no water stress, was higher (4.7 $\mathrm{g} \cdot$ plant $\left.^{-1}\right)$.

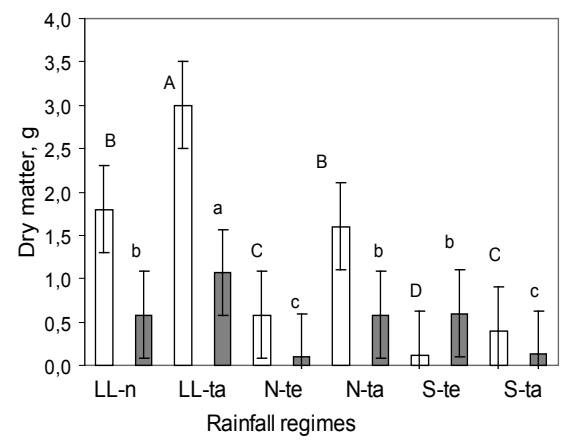

Figure 2. Dry matter produced by Avena barbata under different simulated rainfall regimes of the semiarid Metropolitan Region, Chile. Bars with different upper case and lower case letters were statistically different according to Student-Neuman-Keuls (SNK) $(\mathrm{p} \leq 0.05)$ for shoots (open bars) and roots (dark bars), respectively. Vertical lines in each bar $=$ standard error.

This phenomenon may be explained by considering that a late distribution of rainfall allows the species to be in more favorable temperature conditions as water becomes available for development (Calderón, 2004). Nevertheless, it is worth mentioning that in the case of the earlynormal and late-dry rainy years, which started their growth in September, when the mean temperature exceeded $21^{\circ} \mathrm{C}$ and maximum temperatures reached $32^{\circ} \mathrm{C}$, a water deficit condition may have occurred, causing reduced aerial and radical development.

Higher production of root dry matter was obtained in rainy years. The rainy-normal year was similar to the year of reference, while root dry matter production decreased in years with normal precipitation and was lower still in dry years. However, the dominant effect of rain distribution was proved again as there were no differences between the normal-rainy, late-normal and early-dry years when the distribution changed. This supports findings by Huang and Gao (2000) and Huang and Fry (1998), who determined that the root system was modified by changing its length, density and/or dry matter 
yield according to the water conditions of the environment.

The root/shoot relation presented a low value $(0.17)$ when the plants were maintained without water restriction; when the rainfall regimens were applied, these values increased (between 0.32 and 0.5 ), reaching a maximum in the drynormal year (3.0) when it presented good radical development and scarce shoot growth. Li et al. (2008) indicated that climatic variables explain changes in this relation (46-50\%) better than soil variables $(19 \%)$.

The phenological vegetative and reproductive stages were well defined and exhibited scarce differences between treatments; the total cycle was similar in the different rainfall regimens applied. Superposition among the different phases was present during the reproductive stage, especially during flowering, seed maturation and senescence (Table 1). The beginning of the emergence was uniform (between 10 and 12 days after the first rain). However, the duration of this phase was very short in the treatment of reference (5 days), which determined the beginning of the foliation phase two weeks early. Seemingly, rainfall distribution had an influence, as the normal distribution had a lateflowering beginning in rainy years (between 98 and 129 days) and a short phase of seed maturation (between 19 and 38 days), which would affect seed production. In general, this is coherent with results in A. sterilis obtained by Volis (2007).

The beginning and duration of the tillering and foliation of tiller phases were more precocious and longer in treatments with rainy regimens and, if the total period between the beginning of foliation and the end of the tillering phase is observed, the treatment without water restriction presented a longer period.

In the early-normal and early-dry treatments, the cycle only reached the foliation and cluster phase, probably due to the lower humidity available at the end of the cycle due to lack of rain, which did not allow the development of the reproductive stage in the early distributions. Nielsen and Nelson (1998) state that a water shortage during vegetative growth may reduce the foliar area, advancing the senescence and death of leaves and affecting reproductive growth. As a consequence, it is likely that an early rain distribution would affect the natural resowing in $A$. barbata, especially in dry and normal years. Ghani et al. (2002), working with $H$. vulgare and $H$. spontaneum, determined that the crossed pollination rate was reduced to $0 \%$

Table 1. Time elapsed (days) from sowing to begin (I) to the end (T) of each Avena barbata phenophase and their total duration (D) under different simulated rainfall regimes.

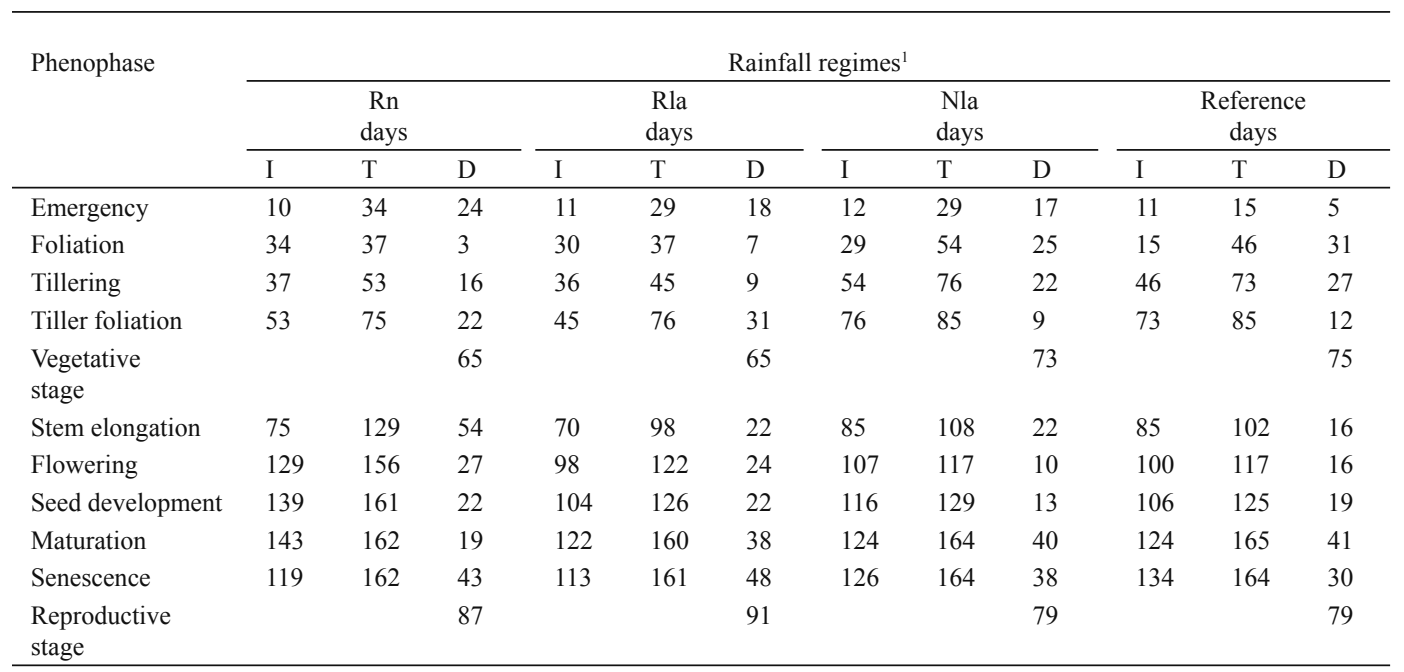

${ }^{1}$ Simulated rainfall regimes are $\mathrm{Rn}=$ Rainy-normal $(628 \mathrm{~mm}), \mathrm{Rla}=$ Rainy-late $(671 \mathrm{~mm}), \mathrm{Nla}=$ Normal-late $(281 \mathrm{~mm})$. 
in arid sites with $150 \mathrm{~mm}$ of rain annually and would increase in semiarid and humid regimens ( 0.4 and $1 \%$ respectively) up to $600 \mathrm{~mm}$ of rain a year, which supports the findings of this study.

All variables of reproductive growth were higher than the rest of the situations studied when $A$. barbata was maintained without water restriction (reference treatment). This shows the importance of water availability in the expression of its productive potential (Table 2). The years with late precipitation distributions showed a higher number of floral stems and seeds per plant, and weight in fruits and seeds was many times higher (Table 3). Thus, it is likely that in years with late rains, the soil would keep enough water available to produce more seeds than are produced in better temperature conditions, creating a higher resowing potential. Kokubun et al. (2001) state that when a water stress is present during the reproductive stage, as for example during the flowering phase, more abortions, pistil and stamen decay could occur, finally resulting in reduced production of reproductive structures.
Table 2. Mean values of growth parameters obtained in Avena barbata without water stress in a soil kept at $66.7 \%$ of its field water capacity.

\begin{tabular}{|c|c|}
\hline Variable & Values \\
\hline Shoot (S) dry matter, g plant $^{-1}$ & 4.7 \\
\hline Roots (R) dry matter, g plant ${ }^{-1}$ & 0.8 \\
\hline Ratio R/S & 0.2 \\
\hline Total fruits, $\mathrm{N}^{\circ}$ & 282.0 \\
\hline Fruits weight, mg & $1,040.0$ \\
\hline Seeds weight, mg & 562.0 \\
\hline Flower stems, $\mathrm{N}^{\circ}$ & 7.7 \\
\hline Vain seeds, $\mathrm{N}^{\circ}$ & 152.0 \\
\hline Filled seeds, $\mathrm{N}^{\circ}$ & 130.0 \\
\hline Seeds, \% & 54.0 \\
\hline Annexes, \% & 46.0 \\
\hline Germination, \% & 89.9 \\
\hline Viability, \% & 96.1 \\
\hline Seed size, $\mathrm{mm}$ & 6.3 \\
\hline REI & 0.2 \\
\hline RI & 20.2 \\
\hline
\end{tabular}

It is worth mentioning that in two distributions of rainy years, there was a great difference in the total fruit weight, although they presented a similar number of floral stems. It is reasonable that the late distribution favors the process of seed maturation and filling, as having more water available would improve the transportation

Table 3. Effect of rainfall quantity and distribution on the production of floral stems, total fruit weight, and number and weight of seeds of Avena barbata.

\begin{tabular}{lllll}
\hline Treatments & $\begin{array}{l}\text { Flower stems } \\
\text { no. }\end{array}$ & $\begin{array}{l}\text { Total fruit weight } \\
\mathrm{mg}\end{array}$ & $\begin{array}{l}\text { Total seeds } \\
\text { no. }\end{array}$ & $\begin{array}{l}\text { Total seed weight } \\
\mathrm{mg}\end{array}$ \\
\hline Rainy normal & $1.2 \mathrm{a}^{1}$ & $30 \mathrm{~b}^{1}$ & $13.5 \mathrm{~b}^{1}$ & $17 \mathrm{~b}^{1}$ \\
Rainy late & $1.4 \mathrm{a}$ & $237 \mathrm{a}$ & $41.9 \mathrm{a}$ & $105 \mathrm{a}$ \\
Normal early & $0.0 \mathrm{~b}$ & $0 \mathrm{~b}$ & $0.0 \mathrm{~b}$ & $0 \mathrm{~b}$ \\
Normal late & $1.3 \mathrm{a}$ & $215 \mathrm{a}$ & $34.5 \mathrm{a}$ & $108 \mathrm{a}$ \\
Dry early & $0.0 \mathrm{~b}$ & $0 \mathrm{~b}$ & $0.0 \mathrm{~b}$ & $0 \mathrm{~b}$ \\
Dry late & $0.1 \mathrm{~b}$ & $0 \mathrm{~b}$ & $1.4 \mathrm{~b}$ & $0 \mathrm{~b}$ \\
\hline
\end{tabular}

${ }^{1}$ Means followed by different letters in each column are statistical different according to the Student-Neuman-Keuls' test $(\mathrm{p} \leq 0.05)$.

of assimilates and other substances toward the seeds. In the aridity or water restriction conditions, the seeds produced by $H$. spontaneum and A. sterilis are mainly vain (Volis, 2007). In addition, it is noteworthy that the normal-rainy year resulted in lower fruit production expressed in total weight than the late-normal year. Supposedly, A. barbata is able to control its reproductive growth according to the time and stage at which water is available, rather than according to the total amount of fallen rain.
If seed quality is analyzed (Table 4), it is possible to infer that when there is enough humidity for the species to end its cycle, a late distribution is essential to obtain better quality, expressed by a larger number of full seeds and greater attachment weight. The first would imply a higher potential for resowing, and the larger amount of attachments may be interpreted as a mechanism of seed protection under conditions of early rain (false break), which would cause a great amount of plantlet mortality derived from a reserve of 
Table 4. Effect of simulated rainfall regimes in total production of fill and empty seeds, total weight of seed annexes, reproductive efficiency index (IER) and reproductive index (IR) of Avena barbata.

\begin{tabular}{|c|c|c|c|c|c|c|c|c|}
\hline \multirow[b]{3}{*}{ Treatments } & \multicolumn{6}{|c|}{ Mean seeds production per plant } & \multirow[b]{3}{*}{$\mathrm{REI}^{2}$} & \multirow[b]{3}{*}{$\mathrm{RI}^{2}$} \\
\hline & \multicolumn{2}{|c|}{ Filled } & \multicolumn{2}{|c|}{ Vain } & \multicolumn{2}{|c|}{ Weight $^{1}$} & & \\
\hline & no. & $\%$ & no. & $\%$ & no. & $\%$ & & \\
\hline Rainy-late & $27.3 \mathrm{a}$ & 65 & $14.7 \mathrm{a}$ & 35 & $132 \mathrm{a}$ & 55.7 & $0,06 \mathrm{~b}$ & $9.9 \mathrm{ab}$ \\
\hline Normal-late & $26.6 \mathrm{a}$ & 77 & $7.9 \mathrm{~b}$ & 23 & $107 \mathrm{a}$ & 49.8 & $0.10 \mathrm{a}$ & $14.4 \mathrm{a}$ \\
\hline
\end{tabular}

${ }^{1}$ Dry weight of seed palea, lemma and awn.

${ }^{2}$ REI (reproductive efficiency index) = weight of fill fruits/total dry matter (shoot and root), RI (reproductive index) $=$ number of total seeds/total dry weight. ${ }^{3}$ Means followed by different letters in each column are statistical different according to Student-Neuman-Keuls' test $(\mathrm{p} \leq 0.05)$.

${ }^{4} \mathrm{nd}=$ not determined, were excluded from analysis because seed palea, lemma and awn were not obtained.

transitory type seeds as in the case of annual poaceae, as they would require more water to ensure germination and emergence (Johnston et al., 1998b). It is noteworthy that higher proportions of vain seeds were produced in the rainynormal and dry-late years, thus proving what was established by Kokubun et al. (2001) and Nielsen and Nelson (1998).

The percentages of germination varied between 79 and $91 \%$ and the feasibility between 90 and $96 \%$, without presenting any effect of the amount or distribution of precipitation. There was no difference in the average estimated seed size.

The distribution of plant resources toward reproductive tissues was higher when $A$. barbata was maintained without water restriction. Thus, the REI was approximately double that obtained with a more favorable rainfall regime compared to when there is no water deficit. In this case, the species assigned a great amount of its resources to seed production $(\mathrm{RI}=20.2)$. The late distribution of precipitation also positively influenced the distribution of resources to plant reproduction (Tables 3 and 4), especially in the case of a year with normal-late precipitation.

According to the results, it is possible to conclude that, although the amount and distribution of precipitation affects dry matter production as well as the amount of seeds in A. barbata, it is the late distribution of rain that, to a greater extent, facilitates its vegetative and reproductive development without changing neither the germinative capacity nor seed viability.

\section{Resumen}

A. Olivares, M. Johnston y C. Calderón. 2009. Efecto del régimen pluviométrico sobre la producción y calidad de semillas de Avena barbata. Cien. Inv. Agr. 36(1): 69-76. Se evaluó, en condiciones controladas de invernadero, el efecto de la cantidad y distribución de las precipitaciones sobre la producción y calidad de semillas de Avena barbata, en un diseño de bloques al azar con cinco repeticiones (maceta). Se establecieron siete tratamientos a partir de años reales del secano de la Región Metropolitana: lluvioso-normal (1982), lluvioso-tardío (1987), normal-temprano (1962), normal-tardío (1989), seco-temprano (1981) y seco-tardío (1990) más uno de referencia sin restricción hídrica. Se sembraron semillas del año, en macetas con suelo desinfectado, dejando las cinco plantas mas uniformes en tamaño y sanidad. Las lluvias simuladas se aplicaron según el calendario del año seleccionado. Se evaluó la producción de fitomasa aérea y radical, la cantidad de tallos florales, de frutos y de semillas, sus pesos totales y el de sus anexos y el llenado de las semillas; la viabilidad de éstas y la capacidad germinativa. El año lluvioso con distribución tardía favoreció una mayor producción de fitomasa, en cambio, la calidad de las semillas fue mejor en los años con distribución tardía, fuese éste normal o 
lluvioso; la proporción de semillas llenas fue mayor en el año lluvioso-normal y el de anexos en el lluvioso-tardío. Los resultados muestran que la respuesta al monto de las lluvias se modifica con la distribución de ellas.

Palabras clave: Avena, crecimiento, déficit hídrico, desarrollo, semillas.

\section{References}

Aronson, J., A. Rigel, and A. Shmida. 1993. Reproductive allocation strategies in desert and Mediterranean populations of annual plants grown with and without stress. Oecology 93:336-342.

Castellaro, G., and F. Squella. 2006. Modelo simple de simulación para la estimación del crecimiento, fenología y balance hídrico de praderas anuales de clima Mediterráneo. Agricultura Técnica (Chile) 66:271-282.

Castellaro, G., M. Silva, and F. Santibáñez. 1994. Efecto de la radiación solar y la temperatura sobre las fenofases de algunas especies del pastizal mediterráneo semiárido. Avances en Producción Animal 19:65-75.

Ghani, A.H.A., H.K. Parzies, and H.H. Geiger. 2002. Estimation of outcrossing rate in Hordeum spontaneum and barley landraces from Jordan. Heredity 41:49-62.

Herrera, F., W.R. Ocumpaugh, J.A. Ortega, J. LloydReilley, G.A.Rasmussen, and S. Maher. 2008. Environmental influences on seed quality of Windmillgrass ecotypes in South Texas. Agronomy Journal 100:1205-1210.

Huang, B. y J. Fry. 1998. Root anatomical, physiological and morphological responses to drought stress for tall fescue cultivars. Crop Science 38:1017-1022.

Huang, B., and H. Gao. 2000. Root physiological characteristics associated with drought resistance in tall fescue cultivars. Crop Science 40:196203.

ISTA. 2008. Internacional Rules for Seed Testing. Versión 2008. Internacional Seed Testing Association. Switzerland

Johnston, M., A. Olivares, and X. Contreras. 1998a. El banco de semillas del suelo y su respuesta a regímenes pluviométricos simulados. II. Géneros de interés forrajero. Avances en Producción Animal 23:55-65.

Johnston, M., A. Olivares, V. García de Cortazar, and X. Contreras. 1998b. El banco de semillas del suelo y su respuesta a regímenes pluviométricos simulados. I. Comunidad de terófitas del mediterráneo semiárido. Avances en Producción Animal 23:45-54.

Johnston, M., A. Olivares, and C. Gutiérrez. 2005. Efecto del régimen pluviométrico de la Región Metropolitana en la producción y calidad de semillas Bromus berteroanus. Agro-Sur 33:1-8.

Kokubun, M., S. Shimada, and M. Takahashi. 2001. Flower abortion caused by preanthesis water deficit in not attributed to impairment of pollen in soybean. Crop Science 41:1517-1521.

Li, Y., T. Luo, and Q. Lu. 2008. Plant height as a simple predictor of the root shoot ratio: Evidence from alpine grasslands on the Tibetan Plateau. Journal Vegetation Science, 19:245-252.

Marques, M.C.M., and P.E.A.M. Oliveira. 2008. Seasonal rhythms of seed rain and seedling emergence in two tropical rain forests in southern Brazil. Plant Biology 10:596-603.

Nielsen, D., and Nelson, N. 1998. Black bean sensitivity to water stress and various growth stages. Crop Science 38:422-427.

Olivares A., and K. Ormazabal. 2006. Efecto de la altura de remanente en la emergencia de la pradera anual. XXXI Congreso Anual Sociedad Chilena Producción Animal, Chillán. Libro Resúmenes Ampliados 31:65-66.

Olivares, A., M. Johnston, and C. Beck. 1997. Emergencia de especies de la pradera natural de tipo mediterráneo en relación con la humedad del suelo. Avance en Producción Animal 22:23-29.

Olivares, A., M. Johnston, and X. Contreras. 1998. Régimen pluviométrico del secano interior de la Región Metropolitana. Avances en Producción Animal 23:35-43.

Olivares A., M. Johnston, and C. Gutiérrez. 2006. Crecimiento y desarrollo de Bromus berteroanus Colla. sometido a diferentes regimenes pluviométricos. Agricultura Técnica (Chile) 66:166-173.

Volis, S. 2007. Correlated patterns of variation in phenology and seed production in populations of two annual grasses along an aridity gradient. Evol. Ecol. 21:381-393. 